\title{
The Effects of Different Types of Biochar on Ammonia Emissions during Co-composting Poultry Manure with a Corn Leaf
}

\author{
Rong Rong ${ }^{1}$, Yusheng Zheng ${ }^{1 *}$, Fengsong Zhang ${ }^{2 * *}$, Linsheng Yang ${ }^{2}$, Zhiming Li ${ }^{1}$ \\ ${ }^{1}$ Key Laboratory of Tropical Biological Resources of Ministry of Education, Department of Bioengineering, \\ Hainan University, Haikou, China \\ ${ }^{2}$ Key Laboratory of Land Surface Pattern and Simulation, Institute of Geographic Sciences \\ and Natural Resources Research, Chinese Academy of Sciences, Beijing, China
}

Received: 23 July 2018

Accepted: 16 September 2018

\begin{abstract}
Composting of poultry manure (PM) can cause several problems, including ammonia $\left(\mathrm{NH}_{3}\right)$ emissions. Biochar is a useful material in the composting process due to its microstructure and sorption properties. This research aims to investigate the changes in $\mathrm{NH}_{3}$ emissions and its relationship with physicochemical properties and the bacterial community during PM composting with different biochar. Seven treatments were carried out with a 2:1 ratio of PM and corn leaf (dry weight basis), i.e. compost with no biochar (control); compost with 5\%,10\% and $15 \%$ wheat stalk biochar (WSB); and compost with $5 \%, 10 \%$ and $15 \%$ rice husk biochar (RHB). The results indicated that adding WSB and RHB could obviously $(\mathrm{p}<0.05)$ reduce $\mathrm{NH}_{3}$ emissions by $53.4-88.7 \%$ and $62.5-89.3 \%$, respectively. And the volatilization of $\mathrm{NH}_{3}$ in RHB treatment was lower than that in WSB treatment at the same ratio. Higher surface areas of $\mathrm{RHB}$ could adsorb more $\mathrm{NH}_{4}^{+}$and $\mathrm{NH}_{3}$ to reduce the volatilization of $\mathrm{NH}_{3}$ at the thermophilic composting stage. The analysis of the bacterial community in compost indicated that adding biochar could decrease the population of Ureibacillus thermosphaericus involved in the oxidative deamination process, which further reduced the $\mathrm{NH}_{4}^{+}-\mathrm{N}$ content and the emission of $\mathrm{NH}_{3}$. Thus, RHB is suggested to be added into PM composting with a ratio of $15 \%$.
\end{abstract}

Keywords: biochar, ammonia emission, composting, poultry manure

\section{Introduction}

The poultry industry is developing rapidly to satisfy the global demands for more meat, resulting in great increases in poultry manure (PM). One environmental

*e-mail: 464531655@qq.com

**e-mail: zhangfs@igsnrr.ac.cn problem brought by PM generation is the emission of ammonia $\left(\mathrm{NH}_{3}\right)$ from $\mathrm{PM}$ [1]. Composting has been proven to be an effective technique to transform manure into a safe and stable product, which may even act as a nutrient source and substrate for plant cultivation [2-3]. However, the element of $\mathrm{N}$ is still lost by the volatilization of $\mathrm{NH}_{3}$ in the composting process [4]. Studies have shown that up to $50-88 \%$ of total $\mathrm{N}$ in 
PM can be lost in the form of $\mathrm{NH}_{3}$ in the composting process [5].

Lots of approaches have been proposed to reduce $\mathrm{NH}_{3}$ emissions during composting, e.g., applying different types of bulking agents [6], increasing aeration rate [7], and adding mineral additives and chemical agents [8-9]. To date, using biochar produced by pyrolysis of carbonaceous material to reduce $\mathrm{NH}_{3}$ emission in composting is attracting increased interest from researchers. Biochar amendment affects the structure of bacteria diversity and adsorbs the watersoluble $\mathrm{NH}_{4}^{+}$and gaseous $\mathrm{NH}_{3}$ during composting [10-12] due to its special properties of chemical composition, sorption performance and porosity. For example, Steiner et al. [10] reported a composting process for PM by applying wood biochar. It was found that the addition of $20 \%(\mathrm{w} / \mathrm{w})$ biochar could accelerate biodegradation during composting and decrease $\mathrm{NH}_{3}$ emissions by $52 \%$. Biochar prepared by different kinds of feedstocks shows different physiochemical features, e.g., pore volume and surface area [13]. An investigation was performed to compare the influences of different kinds of biochar on the emission of $\mathrm{NH}_{3}$ in composting. It was found that total volatilization of $\mathrm{NH}_{3}$ by cornstalk biochar treatment $(10 \%, \mathrm{w} / \mathrm{w})$ was lower than that by other biochar treatments $(10 \%, \mathrm{w} / \mathrm{w})$, possibly resulting from the larger pore volume and larger surface area of cornstalk biochar [14]. Besides, Liu et al. [12] found that biochar could promote the growth of actinomycetes to a certain degree and optimize the composting environment, which probably helps to reduce $\mathrm{NH}_{3}$ emissions in the thermophilic phase. Although biochar has shown its excellent performance in reducing $\mathrm{NH}_{3}$ emissions according to previous research, little is known about the influences of different kinds of biochar on the changes in $\mathrm{NH}_{3}$ emissions and its relationship with special physicochemical properties and biological process taking place in the composting matrix with the biochar addition.

This research aims to assess the impact of different biochar (wheat stalk biochar (WSB) and rice husk biochar (RHB)) on $\mathrm{NH}_{3}$ emissions, $\mathrm{NH}_{4}^{+}$contents and microbial community structure during PM composting in order to elucidate the possible mechanisms involved.

\section{Materials and Methods}

\section{Composting Experiment}

PM and corn leaf (CL) were obtained from a broiler house and a farm near Beijing, China. Wheat stalk biochar (WSB) and rice husk biochar (RHB) were purchased from Henan Yuzhongao Agricultural Technology Co., Ltd. and Zhejiang Guomei Horticulture Co., Ltd. in China, respectively. The WSB and RHB were prepared at temperatures of $500-600^{\circ} \mathrm{C}$ via dry and slow pyrolysis at atmospheric pressure for $6 \mathrm{~h}$.
Table 1 shows the selected physicochemical features of the materials.

Composting was carried out by mixing $\mathrm{CL}$ and $\mathrm{PM}$ at a 1:2 ratio, DM (dry matter) basis, to form a $\mathrm{C} / \mathrm{N}$ ratio of about 15:1, a ratio with which $\mathrm{NH}_{3}$ loss was anticipated. Two types of biochar were added separately at 5\%,10\% and 15\% w/w (dry weight basis) to the CL/PM raw mixture. Seven treatments were carried out, i.e. compost with no biochar (control), compost with 5\%,10\% and 15\% WHB (WSB5, WSB10 and WSB15), and compost with 5\%,10\% and $15 \%$ RHB (RHB5, RHB10 and RHB15). Each treatment was replicated three times.

The experiment was carried out in separate reactors $(0.5 \mathrm{~m} \times 0.5 \mathrm{~m} \times 0.8 \mathrm{~m})$ for $54 \mathrm{~d}$. Fresh air was transferred into each reactor through the perforation plates from the bottom by the help of an air pump. Aeration rate was maintained at $0.5 \mathrm{~L} / \mathrm{min}$ during composting. The composting mixtures were turned once a week. Water was sprayed onto the compost to maintain a moisture content of $60 \% \mathrm{w} / \mathrm{w}$, and to achieve the uniform distribution of moisture. The compost temperature and ambient temperature were observed three times a day and the mean value was recorded.

\section{Sampling and Analysis}

During the composting process, the homogeneous compost samples with a weight of $1000 \mathrm{~g}$ were taken on days $0,2,8,16$ and 54 . The samples were first freezedried, powdered in an agate mortar, and then filtered by a $0.1 \mathrm{~mm}$ sieve, and divided into two groups; one was stored at $-20^{\circ} \mathrm{C}$ to measure $\mathrm{pH}$, total $\mathrm{N}(\mathrm{TN})$, total $\mathrm{C}$ (TC) and $\mathrm{NH}_{4}^{+}-\mathrm{N}$, while the other was stored at $-80^{\circ} \mathrm{C}$ for DNA extraction.

The $\mathrm{NH}_{3}$ concentration in the outlet air was measured at different times (2 a.m., 6 a.m., 10 a.m., 2 p.m., 6 p.m. and 10 p.m.) using a portable biogas analyzer (GA5000, Geotech, UK) that could measure the $\mathrm{NH}_{3}$ up to $1000 \mathrm{ppm}$ and the average value was recorded. The $\mathrm{pH}$ values of the composting mixtures and raw materials were gauged in water extracts with a ratio of 1:10 (w/v) using a $\mathrm{pH}$ meter (PHS-3C, Leici, China). Total $\mathrm{N}(\mathrm{TN})$ and total $\mathrm{C}$ (TC) were analyzed by an elemental analyzer (Elementar Vario MACRO cube, Elementar, Germany). $\mathrm{NH}_{4}^{+}-\mathrm{N}$ was extracted in a $2 \mathrm{~mol} / \mathrm{L} \mathrm{KCl}$ solution $(1: 10(\mathrm{w} / \mathrm{v}))$ and gauged first by the indophenol blue method and second by colorimetry [15]. The Brunauer-Emmett-Teller (BET) surface areas of WSB and RHB were measured through a 50-point gas adsorption test where $\mathrm{N}_{2}$ was used as the adsorbate. The measurement of surface area and the analysis of pore size were carried out by Micromeritics ASAP 2460 Surface Area and Porosimetry Auto Analyser (ASAP 2460, Micromeritics, USA).

The extraction of total genomic DNA was achieved by a FastDNA Spin Kit for Soil (MP, USA). The quality and concentration of DNA were evaluated by NanoDrop ND-2000c (Theromo Fisher Scientific, 
Table 1. Basic properties of compost material.

\begin{tabular}{|c|c|c|c|c|c|c|}
\hline Materials & $\mathrm{TC}(\%)$ & $\mathrm{TN}(\%)$ & $\mathrm{C} / \mathrm{N}$ & $\mathrm{pH}$ & Pore volumes $\left(\mathrm{cm}^{3} \cdot \mathrm{g}^{-1}\right)$ & Surface $\operatorname{area~}\left(\mathrm{m}^{2} \cdot \mathrm{g}^{-1}\right)$ \\
\hline Poultry manure & 11.69 & 1.63 & 7.17 & 7.08 & - & - \\
\hline Corn leaf & 35.32 & 0.89 & 39.69 & 7.80 & - & - \\
\hline Wheat stalk biochar & 7.80 & 0.19 & 41.05 & 9.10 & 0.064 & 26.49 \\
\hline Rice husk biochar & 17.76 & 0.38 & 46.74 & 8.91 & 0.042 & 42.78 \\
\hline
\end{tabular}

USA). The extracted DNA was amplified by universal primers U341F (ACTCCTACGGGAGGCAGCAG) and U806R (GGACTACHVGGGTWTCTAAT) [16], which target the hypervariable V3-V4 regions of the bacterial $16 \mathrm{~S}$ rRNA gene. The PCR mixture $(25 \mu \mathrm{L})$ contained $0.25 \mathrm{mM}$ of a dNTP mixture, $5 \times$ PCR buffer $\left(\mathrm{Mg}^{2+}\right.$ Plus), $1.0 \mu \mathrm{M}$ of each primer, $10 \mathrm{ng}$ of genomic DNA template and $0.5 \mathrm{U}$ of Taq DNA Polymerase (TaKaRa, China). The PCR amplification process consisted of an initial denaturation at $95^{\circ} \mathrm{C}$ for $2 \mathrm{~min}$, followed by 30 cycles of denaturation at $95^{\circ} \mathrm{C}$ for $20 \mathrm{~s}$, annealing at $55^{\circ} \mathrm{C}$ for $30 \mathrm{~s}$ and extension at $72^{\circ} \mathrm{C}$ for $30 \mathrm{~s}$, and finally a $5 \mathrm{~min}$ extension stage at $72^{\circ} \mathrm{C}$. Purification and quantification were conducted on the products using a PCR product purification kit (TIANGEN, China) and a Qubit 2.0 fluorometer (Life Technologies, China), respectively. Equal molar quantity of the PCR products from each sample were sent out to Mega Co., Ltd. in Beijing for the construction of small-fragment library and pair-end sequencing by an Illumina MiSeq sequencing system (Illumina, USA).

\section{Statistical Analysis}

All the physicochemical analyses were carried out three times. The difference of data was subject to the comparison on least significance difference (LSD) at $\mathrm{p}=0.05$ by SPSS v.18.0.

\section{Results and Discussion}

\section{Variation in Temperature during Composting}

Temperature acts as a significant factor in evaluating the composting process as well as the microbial activities in the process. Fig. 1 shows the changes of temperature in all treatments. In each treatment, temperatures all increased rapidly and peaked on day 2 , i.e., $75^{\circ} \mathrm{C}, 79^{\circ} \mathrm{C}, 77^{\circ} \mathrm{C}, 80^{\circ} \mathrm{C}, 76^{\circ} \mathrm{C}, 77^{\circ} \mathrm{C}$ and $76^{\circ} \mathrm{C}$ for the treatments of control, WSB5, WSB10, WSB15, RHB5, RHB10 and RHB15, respectively. Then all treatments were turned over on day 8 , resulting in a little increase in temperature due to the secondary fermentation of organic substances. As the organic substances were depleted, the temperature decreased gradually and approached the ambient temperature at the end of the composting process. The variation in temperature was

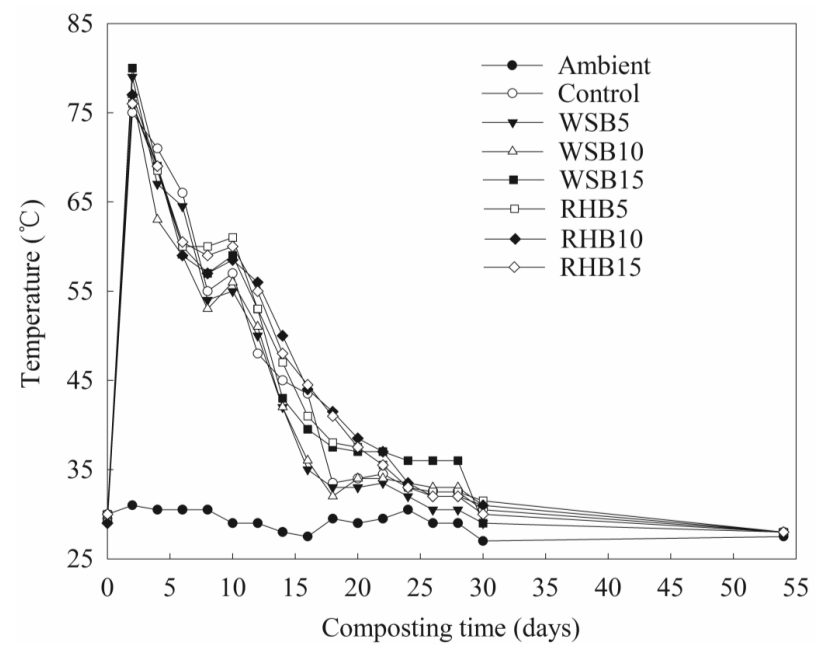

Fig. 1. Changes in temperature during composting process.

similar with an earlier report by Liu et al. [12], who took bamboo biochar as an additive in the composting of PM.

The temperature trends in this study showed that the longest thermophilic phase $\left(>50.0^{\circ} \mathrm{C}\right)$ occurred in the RHB10 treatment $(14 \mathrm{~d})$ and the shortest phase in the control (11 d), while the WSB5, WSB10, WSB15, RHB5, and RHB15 treatments had the thermophilic phases for $12 \mathrm{~d}, 12 \mathrm{~d}, 12 \mathrm{~d}, 13 \mathrm{~d}$ and $13 \mathrm{~d}$, respectively. Compared with the control treatment, the addition of WSB and RHB prolonged the thermophilic phase of PM composting. Similarly, Sánchez-García et al. [17] observed a slightly longer thermophilic phase of composting with biochar. This could be explained by the large surface area and high water retention capability of biochar, which offered suitable conditions for microorganisms [18-19].

\section{Variations in $\mathrm{pH}$ during Composting}

As shown in Fig. 2, the $\mathrm{pH}$ values of the seven treatments all tended to increase in the composting process, and RHB10 showed the largest final value of 8.64 and the control showed the smallest final value of 8.06. During composting, the biochar-amended treatments had higher $\mathrm{pH}$ value than the control, which was consistent with Agyarko-Mintah et al. [20], who found that the $\mathrm{pH}$ values increased in the composting process from initial 7.38 and 7.26 to the final 8.12 and 7.80 for the poultry litter biochar-amended treatment and the control, respectively. Generally, the increase in $\mathrm{pH}$ 


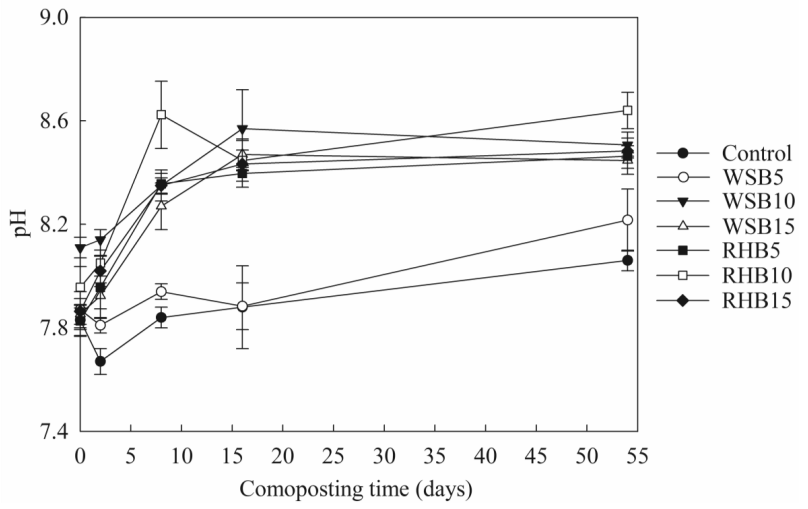

Fig. 2. Changes in $\mathrm{pH}$ during composting process.

values could be a result of decomposition of nitrogenous compounds. In this study, treatment-added RHB had a significantly higher final $\mathrm{pH}$ value than WSB added in the same proportion of biochar. This could be attributed to the acid-neutralizing ability of biochar [21] and the fact that RHB biochar with larger specific surface area (Table 1) absorbed more $\mathrm{NH}_{3}$ which is alkaline, and this possibly led to the increase in the value of $\mathrm{pH}$.

\section{$\mathrm{C} / \mathrm{N}$}

Nitrogen and carbon contribute greatly to energy generation and cell growth in composting, and the amount of nitrogen and carbon elements is significantly changed in this process. Therefore, the $\mathrm{C} / \mathrm{N}$ ratio was adopted in this research to evaluate the maturity of compost. The $\mathrm{C} / \mathrm{N}$ ratio decreased in all the treatments: by 2.81 in control, 2.85 in WSB5, 4.94 in WSB10, 4.67 in WSB15, 5.22 in RHB5, 5.28 in RHB10, and 7.24 in RHB15. The results obtained in this research were similar with those by Agyarko-Mintah et al. [20], who reported that the $\mathrm{C} / \mathrm{N}$ ratio declines in poultry litter composting. Zhang et al. [22] also pointed out that the $\mathrm{C} / \mathrm{N}$ ratio was reduced by $8.0-10.0$ in the composting

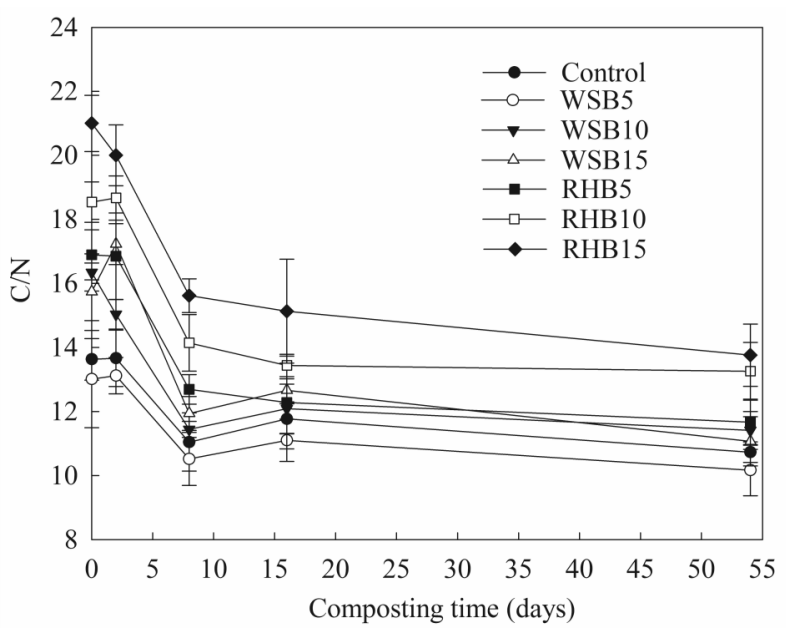

Fig. 3. Changes in $\mathrm{C} / \mathrm{N}$ during composting process. process of pig manure with wheat-straw biochar, which were pyrolyzed at $500-600^{\circ} \mathrm{C}$.

The results showed that $\mathrm{C} / \mathrm{N}$ ratio of treatments with biochar dropped more than that of treatment in control. Sánchez-García et al. [17] found that biochar facilitated microbial activity and promoted the degradation of organic substances in the thermophilic phase. Moreover, the addition of RHB for composting led to a greater reduction of the $\mathrm{C} / \mathrm{N}$ than $\mathrm{WSB}$ in the same proportion of biochar, possibly due to difference in the activity of microbes affected by the surface area and microporosity of different biochar. In control, WSB5 and WSB15 treatments, more fluctuations were observed in $\mathrm{C} / \mathrm{N}$ ratio, which could be explained by the moisture content as well as the change of microbial metabolism caused by moisture content [23].

\section{$\mathrm{NH}_{3}$ Emissions}

Ammonia was only detected on days 1 and 2 of composting in all treatments. Fig. 4 presents the change of $\mathrm{NH}_{3}$ levels in the experiment. At the beginning, the amount of $\mathrm{NH}_{3}$ emissions from all treatments increased and reached their maximum values on day 2 , with the $\mathrm{NH}_{3}$ emissions being 42.5, 15.0, 9.2, 3.8, 14.0, 11.4 and $3.9 \mathrm{ppm}$ for the control, WSB5, WSB10, WSB15, RHB5, RHB10, and RHB15, respectively. Compared with the control, the average $\mathrm{NH}_{3}$ emissions of two days were decreased by $53.4 \%, 72.8 \%, 88.7 \%, 62.5 \%, 75.2 \%$ and $89.3 \%$ for WSB5, WSB10, WSB15, RHB5, RHB10, and RHB15, respectively. In addition, as the amount of RHB or WSB increased, less $\mathrm{NH}_{3}$ was detected from the treatments. The results revealed that the addition of WSB and RHB could significantly reduce $\mathrm{NH}_{3}$ emissions, which was in agreement with the study made by Janczak et al. [24], who used willow biochar to decrease $\mathrm{NH}_{3}$ emissions in the composting of chicken manure.

Oxygenated functional groups on the surface of biochar can absorb gaseous and solvent molecules, which may affect $\mathrm{NH}_{3}$ emissions [25-26]. The micro-

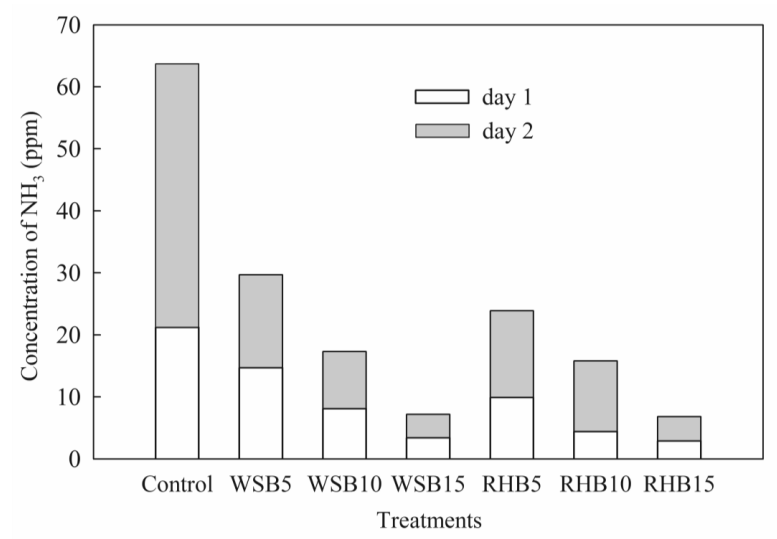

Fig. 4. Changes in concentration of $\mathrm{NH}_{3}$ during composting process. 


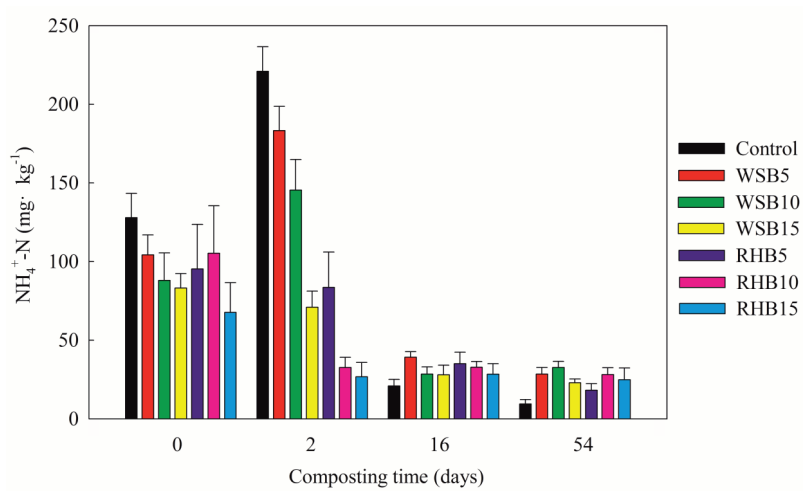

Fig. 5. Changes in $\mathrm{NH}_{4}^{+}-\mathrm{N}$ content during composting process.

pores in biochar form a surface with large area, which increase the number of oxygenated functional groups and thus improve the capacity of surface absorption to easily adsorb $\mathrm{NH}_{4}^{+}$and $\mathrm{NH}_{3}$ [27]. In this study, the average rate of $\mathrm{NH}_{3}$ emissions in RHB treatment was lower than that in WSB treatment at a same additive ratio, which might result from the fact that RHB can adsorb more $\mathrm{NH}_{4}^{+}$and $\mathrm{NH}_{3}$ due to the larger specific surface area (Table 1).

$$
\mathrm{NH}_{4}^{+}-\mathrm{N}
$$

Fig. 5 shows the $\mathrm{NH}_{4}^{+}-\mathrm{N}$ contents in all treatments at different times of composting. During the first two days, the high contents of $\mathrm{NH}_{4}^{+}-\mathrm{N}$ in all treatments might result from the fast decomposition of organic nitrogen compounds and relatively weak nitrification by nitrifying bacteria. Then the decrease was observed in the $\mathrm{NH}_{4}^{+}-\mathrm{N}$ contents of all treatments and little $\mathrm{NH}_{4}^{+}-\mathrm{N}$ was measured at the final stage of composting. The decrease might result from the stability of compost mass and the transformation of $\mathrm{NH}_{4}^{+}-\mathrm{N}$ to $\mathrm{NO}_{3}^{-}-\mathrm{N}$ by nitrobacteria [28]. A similar result was demonstrated by Meng et al. [29], who co-composted sewage sludge and pumice amended with sucrose.
The maximum content was obtained in the control $(220.9 \mathrm{mg} / \mathrm{kg})$ at day 2 , which was significantly higher than that in biochar-amended treatments. The emission rate of $\mathrm{NH}_{3}$ showed a positive correlation with $\mathrm{NH}_{4}{ }^{+} \mathrm{N}$ contents. The low-content $\mathrm{NH}_{4}^{+}{ }^{+} \mathrm{N}$ in biochar-amended treatments indicated that biochar addition might adsorb $\mathrm{NH}_{4}{ }^{+}$and reduce $\mathrm{NH}_{3}$ production during the thermophilic phase. However, on days 16 and 54, the lowest $\mathrm{NH}_{4}{ }^{+} \mathrm{N}$ contents $(20.9 \mathrm{mg} / \mathrm{kg}$ and $9.5 \mathrm{mg} / \mathrm{kg})$ were detected in the control compared with biochar-amended treatments. This might be due to desorption of $\mathrm{NH}_{4}^{+}$from biochar as the composting progressed, which results in a higher content of $\mathrm{NH}_{4}^{+}-\mathrm{N}$ measured in compost-added biochar than that in the control without biochar. In this research, the $\mathrm{NH}_{4}^{+}-\mathrm{N}$ contents of all treatments were lower than those in previous research $[20,22]$, which could be explained by the differences in the selected material in composting.

\section{Bacterial Community}

The condition of bacterial community in the thermophilic phase was investigated by Illumina highthroughput sequencing of the 16S rRNA gene. Seven samples were chosen on day 2 for the investigation of the bacterial community, and more than 70761 sequences were acquired for each sample. Species-level characterization was conducted to find out the bacteria in charge of composting.

The bacteria of the seven samples had similar features in diversity, but different features in abundance. Fig. 6 shows the relative abundance in the bacterial community at species level. Generally, 10 identified species were observed with abundances in the top 10, and Ureibacillus thermosphaericus and Bacillus humi were observed with abundances above $0.001 \%$, which were the dominant species in all samples. The relative abundance of the species, especially the predominant species, differed for different treatments. For the control, Ureibacillus thermosphaericus was $2.86 \%$ of the total bacteria,

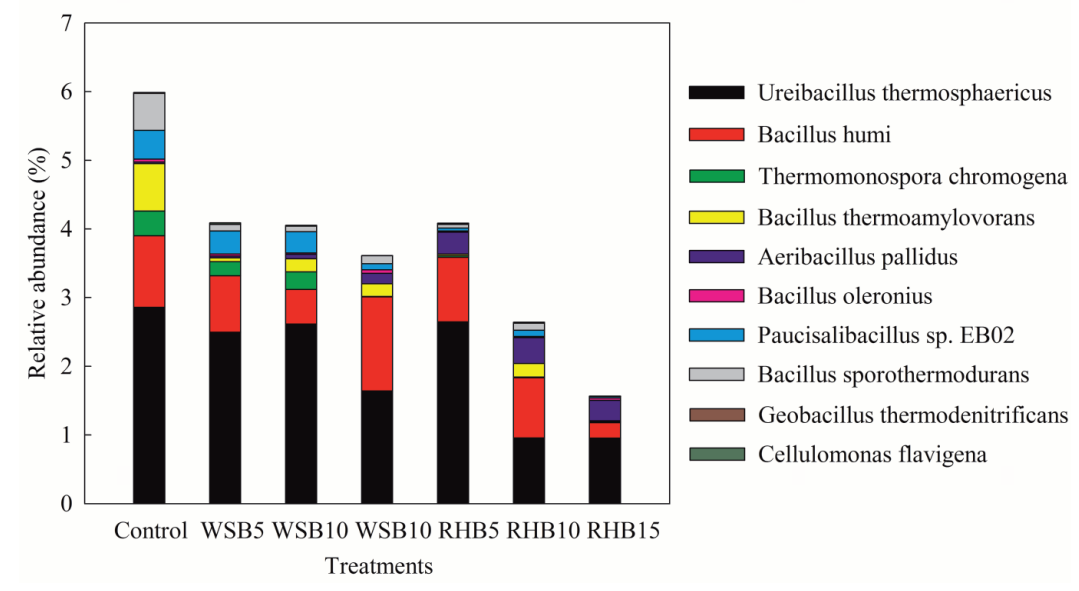

Fig. 6. Relative abundance at the species level of 16S rRNA gene sequences from the bacterial communities of composting. 
and the proportions of Ureibacillus thermosphaericus in WSB5, WSB10, WSB15, RHB5, RHB10 and RHB15 were lower, being $2.50 \%, 2.61 \%, 1.64 \%, 2.65 \%, 0.96 \%$ and $0.95 \%$, respectively. The addition of RHB and WSB clearly reduced the relative abundance of Ureibacillus thermosphaericus.

Akita et al. [30] isolated an Ureibacillus thermosphaericus strain from Japanese compost, and it showed a high capacity in transforming organic nitrogen into ammoniacal nitrogen in the oxidative deamination process. The results in this research indicate that the addition of WSB and RHB can inhibit the growth of Ureibacillus thermosphaericus and thus reduce $\mathrm{NH}_{3}$ production in composting. Further research is required to investigate the relationships among biochar, the bacterial community and deamination.

\section{Conclusions}

In the composting process, WSB and RHB could lower $\mathrm{NH}_{3}$ volatilization by $53.4-88.7 \%$ and $62.5-89.3 \%$, respectively. The $\mathrm{NH}_{4}^{+}-\mathrm{N}$ contents in the biocharadded treatments were significantly lower than that in the control when $\mathrm{NH}_{3}$ was emitted at a high rate. The population of Ureibacillus thermosphaericus, with a high oxidative deamination capacity in biochar-amended treatments, decreased by $7.3-66.8 \%$ compared with the control treatment. In conclusion, our results suggest that $\mathrm{NH}_{3}$ volatilization was inhibited more by the addition of RHB, which could be explained by RHB being able to adsorb more $\mathrm{NH}_{4}^{+}$and $\mathrm{NH}_{3}$ due to the larger surface area. Additionally, oxidative deamination by Ureibacillus thermosphaericus could be diminished by adding biochar during co-composting PM with $\mathrm{CL}$, which also reduced the $\mathrm{NH}_{4}^{+}-\mathrm{N}$ content and $\mathrm{NH}_{3}$ emissions.

\section{Acknowledgements}

We are grateful to the anonymous referees and the editorial board for reviewing this paper.

\section{Conflict of Interest}

The authors declare no conflict of interest.

\section{References}

1. GARCIA-GONZALEZ M.C., VANOTTI M.B. Recovery of ammonia from swine manure using gas-permeable membranes: Effect of waste strength and $\mathrm{pH}$. Waste Manage. 38 (1), 455, 2015.

2. KULCU R., YALDIZ O. The composting of agricultural wastes and the new parameter for the assessment of the process. Ecol. Eng. 69 (4), 220, 2014.
3. WANG R., ZHANG J., SUI Q., WAN H., TONG J., CHEN M., WEI Y., Wei D. Effect of red mud addition on tetracycline and copper resistance genes and microbial community during the full scale swine manure composting. Bioresour. Technol. 216, 1049, 2016.

4. AHN H. K., MULBRY W., WHITE J.W., KONDRAD S.L. Pile mixing increases greenhouse gas emissions during composting of dairy manure. Bioresour. Technol. 102 (3), 2904, 2011

5. OGUNWANDE G.A., OSUNADE J.A., ADEKALU K.O., OGUNJIMI L.A.O. Nitrogen loss in chicken litter compost as affected by carbon to nitrogen ratio and turning frequency. Bioresour. Technol. 99 (16), 7495, 2008.

6. CHOWDHURY M.A., DE NEERGAARD A., JENSEN L.S. Composting of solids separated from anaerobically digested animal manure: Effect of different bulking agents and mixing ratios on emissions of greenhouse gases and ammonia. Biosyst. Eng. 124, 63, 2014.

7. TSUTSUI H., FUJIWARA T., MATSUKAWA K., FUNAMIZU N. Nitrous oxide emission mechanisms during intermittently aerated composting of cattle manure. Bioresour. Technol. 141 (7), 205, 2013.

8. WANG Q., AWASTHI M.K., REN X., ZHAO J., LI R., WANG Z., CHEN H., WANG M., Zhang Z. Comparison of biochar, zeolite and their mixture amendment for aiding organic matter transformation and nitrogen conservation during pig manure composting. Bioresour. Technol. 245, 300, 2017.

9. MENG L., LI W., ZHANG S., WU C., WANG K. Effects of sucrose amendment on ammonia assimilation during sewage sludge composting. Bioresour. Technol. 210, 160, 2016.

10. STEINER C., DAS K.C., MELEAR N., LAKLY D. Reducing nitrogen loss during poultry litter composting using biochar. J. Environ. Qual. 39 (4), 1236, 2010.

11. MALINSKA K., ZABOCHNICKA-SWIATEK M., DACH J. Effects of biochar amendment on ammonia emission during composting of sewage sludge. Ecol. Eng. 71, 474, 2014

12. LIU N., ZHOU J., HAN L., MA S., SUN X., HUANG G. Role and multi-scale characterization of bamboo biochar during poultry manure aerobic composting. Bioresour. Technol. 241, 190, 2017.

13. INYANG M., DICKENSON E. The potential role of biochar in the removal of organic and microbial contaminants from potable and reuse water: A review. Chemosphere. 134, 232, 2015.

14. CHEN W., LIAO X., WU Y., LIANG J.B., MI J., HUANG J., ZHANG H., WU Y., QIAO Z., LI X., WANG Y. Effects of different types of biochar on methane and ammonia mitigation during layer manure composting. Waste Manage. 61, 506, 2017.

15. LI R., WANG J.J., ZHANG Z., SHEN F., ZHANG G., QIN R., LI X., XIAO R. Nutrient transformations during composting of pig manure with bentonite. Bioresour. Technol. 121, 362, 2012.

16. QIAN X., SUN W., GU J., WANG X.J., ZHANG Y.J., DUAN M.L., LI H.C., ZHANG R.R. Reducing antibiotic resistance genes, integrons, and pathogens in dairy manure by continuous thermophilic composting. Bioresour. Technol. 220, 425, 2016.

17. SANCHEZ-GARCIA M., ALBURQUERQUE J.A., SANCHEZ-MONEDERO M.A., ROIG A., CAYUELA M.L. Biochar accelerates organic matter degradation and enhances $\mathrm{N}$ mineralisation during composting of poultry 
manure without a relevant impact on gas emissions. Bioresour. Technol. 192, 272, 2015.

18. ZHANG L., SUN X. Changes in physical, chemical, and microbiological properties during the two-stage co-composting of green waste with spent mushroom compost and biochar. Bioresour. Technol. 171 (1), 274, 2014.

19. JINDO K., SUTO K., MATSUMOTO K., GARCIA C., SONOKI T., SANCHEZ-MONEDERO M.A. Chemical and biochemical characterisation of biochar-blended composts prepared from poultry manure. Bioresour. Technol. 110, 396, 2012.

20. AGYARKO-MINTAH E., COWIE A., VAN ZWIETEN L., SINGH B.P., SMILLIE R., HARDEN S., FORNASIER F. Biochar lowers ammonia emission and improves nitrogen retention in poultry litter composting. Waste Manage. 61, 129, 2017.

21. VAN ZWIETEN L., KIMBER S., MORRIS S., CHAN K.Y., DOWNIE A., RUST J., JOSEPH S., COWIE A. Effects of biochar from slow pyrolysis of papermill waste on agronomic performance and soil fertility. Plant Soil. 327 (1), 235, 2010.

22. ZHANG J., CHEN G., SUN H., ZHOU S., ZOU G. Straw biochar hastens organic matter degradation and produces nutrient-rich compost. Bioresour. Technol. 200, 876, 2016.

23. WANG C.T., LEE Y.C., LIAO F.Y. Effect of composting parameters on the power performance of solid microbial fuel cells. Sustainability. 7 (9), 12634, 2015.

24. JANCZAK D., MALINSKA K., CZEKALA W., CACERES R., LEWICKI A., DACH J. Biochar to reduce ammonia emissions in gaseous and liquid phase during composting of poultry manure with wheat straw. Waste Manage. 66, 36, 2017.

25. KASTNER J.R., MILLER J., DAS K.C. Pyrolysis conditions and ozone oxidation effects on ammonia adsorption in biomass generated chars. J. Hazard. Mater. 164 (2), 1420, 2009.

26. SYDNEY U., HOOK J.M., KIMBER S. An Investigation into the Reactions of Biochar in Soil. Aust. J. Soil Res. 48 (7), 501, 2010.

27. THIES J.E., RILLIG M.C., GRABER E.R. Biochar effects on the abundance, activity and diversity of the soil biota. In Biochar for Environmental Management: Science, Technology and Implementation, 2nd ed.; Lehmann J, Joseph S, Eds., Routledge: London, UK, Volume 1, 327, 2015.

28. JIANG J., HUANG Y., LIU X., HUANG H. The effects of apple pomace, bentonite and calcium superphosphate on swine manure aerobic composting. Waste Manage. 34 (9), 1595, 2014.

29. MENG L., LI W., ZHANG S., WU C., WANG K. Effects of sucrose amendment on ammonia assimilation during sewage sludge composting. Bioresour. Technol. 210, 160, 2016.

30. AKITA H., FUJINO Y., DOI K., OHSHIMA T. Highly stable meso-diaminopimelate dehydrogenase from an Ureibacillus thermosphaericus strain A1 isolated from a Japanese compost: purification, characterization and sequencing. AMB Express. 1 (1), 43, 2011. 